\title{
Indonesian Double Tax Avoidance (P3B) In International Tax Law
}

\author{
"Graduate Student, Institut STIAMI JAKARTA" \\ "Lecturer, institut STIAMI JAKARTA \\ DOI: 10.29322/IJSRP.11.08.2021.p11635 \\ http://dx.doi.org/10.29322/IJSRP.11.08.2021.p11635
}

Aflintua H. Sormin (BC202120211), Alhabieb Amanggori (BC202120119), Dr.Prianto Budi Saptono

\begin{abstract}
Avoidance of double taxation is an agreement between two countries that regulates the imposition of taxes on income received by residents of one or both parties.

In the Indonesian legal system, the Double Taxation Avoidance Agreement (P3B) is part of the legislation and its provisions are above the national law. It also applies specifically (lex specialist) before the Income Tax law.

Double Taxation Avoidance Agreement (P3B) can be prevented by anticipating it at the time of registration or when the Foreign Tax Subject (SPLN) applies to an income recipient.

It can be seen that the SPLN is the only income earner and has economic substance.
\end{abstract}

Index Terms- Double Taxation Avoidance Agreement (P3B), Tax Treaty, International Tax

\section{BACKGROUND OF THE PROBLEM}

A dvances in technology and ease of transacting with international trade, which is marked by the increasing number of transactions for goods and services, cannot be avoided. Currently, Indonesia as part of the international community must be able to follow the trend of technological progress to establish better economic relations between countries.

Modernization brings changes, so it can be said that interstate law is a law that not only regulates international relations but also deals with agreements that arise as a result of such associations (Brotodihardjo, 2008:223)

Associated with the increase in cross-border transactions, the complexity of taxation will also increase. Taxes arising from the existence of two or more entities of different nationalities in international transactions will undoubtedly determine which jurisdiction in that country is suitable for obtaining income from the resulting taxes.

This cannot be ignored. Taxation on international transaction flows is a form of domestic income tax but includes foreign factors.

Foreign factors can be in the form of differences in nationality, the country where the company is founded, or the form of income obtained from abroad. These foreign factors confuse taxation rights, so it is necessary to determine which tax law applies to transactions and distribution of taxation rights.

By joining Indonesia in international organizations, Indonesia cannot be separated from international tax law, especially international double taxation. International double taxation is a tax imposed more than once on the same object by more than one country. International double taxation generally occurs because there is no international law that regulates it so that there is a legal clash between two or more countries (Suandy, 2008: 253).

\section{THEORY BASIS}

International Tax Law

The definition of tax law as the expert opinion states:

1. According to Prof. Dr. Rochmat Soemitro, stated that international tax law is a national tax law consisting of rules, both in the form of national rules and methods derived from treaties between countries and from principles or customs that have been accepted by both countries in the world, to regulate matters - on taxation matters and where it can be shown the presence of foreign elements.

2. According to Prof. Dr. P.J.A. Adriani, international tax law is a legal entity that deals with an issue regulated in the National Law regarding taxation of foreigners, national regulations to avoid double taxation, and treaties.

3. According to Prof. Mr. H.J. Hofstra, international tax law is a national tax law in which it refers to the imposition of foreigners.

4. According to Dr. P. Verloren van Themaat, international tax law is a whole of norms (customs or international treaties, which limit the sovereignty of a country in tax matters).

Double Tax

International double taxation is a major problem in international tax laws, or more than one country levies taxes on the same object many times, so double taxation can occur because several countries tax the same tax pair at the same time (Suandi,2008:255).

In addition to national tax laws, double taxation treaties are one of the main sources of international tax laws, as they are essentially a reconciliation of two different tax laws.

In one country, double taxation treaties become part of domestic legislation through the approval process, and double taxation treaties may exceed a country's national tax laws. In a dual country, only the provisions of the double taxation avoidance agreement that can be converted into national tax regulations, so that the double taxation avoidance agreement can become part of domestic legislation (Zain, 2007: 272). 
In Indonesia, P3B becomes part of Indonesia's tax provisions through the ratification process and its position is treated as lex specialist to domestic laws (Surahmat, 2000).

To facilitate understanding of International Taxes in terms of Subject and Object Taxes can be categorized into two views:

a. Taxing Inbound Income: Taxing on Domestic Tax Subjects (SPDN) who obtain income sourced from abroad

b. Taxing Outbound Income: Taxing on Foreign Tax Subjects (SPLN) which derives income from domestic sources.

As it is known that the Government is sovereign to impose taxes on every income of Individuals and Entities in economic transactions that generate income. The tax law applies two principles based on these "Connecting factors", namely:

a. Residence Principle (Principle of Residence) The state has the right to tax a person (individual and entity) because there is a personal "attachment" such as residency, domicile, citizenship, place of establishment, or domicile of business entity management.

b. Source Principle The right of the state to impose taxes on a person (individual or entity) because there is an economic attachment, namely income originating from the country.

The division of tax collection rights between the source country and the domicile country in the context of avoiding double taxation is incomplete without the double taxation avoidance method applied by the two countries. A country has the right to choose which method to use in the Tax Treaty following the policies of each country and its national laws.

The Organization for Economic Cooperation and Development (OECD) model is formulated following the needs of tax relations between OECD members as advanced industrial countries with the power to carry out investment abroad (Devano S. \& Kumia S., 2006).

The Organization for Economic Cooperation and Development (OECD) model benefits capital-exporting countries and harms capital-importing countries. Often eliminating double taxation by asking the source country to surrender part or all of the taxation rights on certain incomes received by residents of other countries. It can be concluded that this model prioritizes the domicile principle of the country providing services or investing, where the right to collect taxes is in the domicile country.

The United Nations Model (UN Model) was formulated for the Agreement on the Avoidance of Double Taxation (P3B) between developed and developing countries based on the premise that the Organization for Economic Cooperation and Development (OECD), which mostly asks source countries to give up their tax revenues, is not appropriate to be used as a source of income. Double Taxation Avoidance Approval guide.

From the perspective of income flows between the two groups of countries (income in developed countries is greater than in developing countries). Therefore, insufficient income in developing countries has led to restrictions on the provision of public facilities or public services in developing countries. In addition, in general, developing countries have debt and they do not have the funds to pay off the debt.

The United Nations Model (UN Model) prioritizes the principle of sources of income, because usually those who use services and receive funds from abroad, therefore this model is more suitable for collecting taxes from income-generating countries (Devano S. \& Kumia S., 2006). However. both the United Nations Model (UN Model) and the Organization for Economic Cooperation and Development (OECD), cannot stand alone. Because it depends on the agreement of the two countries when the agreement is determined.

\section{METHODOLOGY}

This research is the discovery and assembly of arthritis related to legal issues; and the field of study concerned drafting an effective authority that addresses such legal questions (Bryan, 1999). Jurisprudence is normative. Research methods include approaches, legal determination of sources, and critical analysis of sources through exploration, investigation, and interpretation.

This research is qualitative research that refers to the legal norms contained in the company's articles of association and court decisions related to the matter. The steps for collecting legal sources include reading, researching, citing, comparing, and contacting legal sources and literature so that they become units that are easy to complete. The collected legal sources are reviewed carefully to avoid mistakes in legal sources; second, the laws collected from these sources but classified according to the source. Third, following the group arrangement, so that there are no errors and systematization of information sources. Then analyze the sources of law according to the category of the problem. The analysis was carried out and written in the form of description, analysis, systematization, interpretation, and evaluation.

\section{DISCUSSION AND DISCUSSION}

4.1 Double Taxation Avoidance Agreement (P3B) in the legal system in Indonesia. (P3B)

1. Legal Position of Double Taxation Avoidance Agreement

From the research that the author did, there was a legal standing of a Tax Treaty that was held between Indonesia and other countries. The legal basis for holding tax treaties between countries. is:

Article 11 paragraph (1) and paragraph (2) of the 1945 Constitution (1) The President with the approval of the House of Representatives declares war, makes peace and treaties with other countries. (2) The President in making other international agreements that have broad and fundamental consequences for the lives of the people related to the burden of state finances, and/or require amendments or the enactment of laws must be approved by the House of Representatives.

Article 32A of Law Number 36 of 2008 concerning Income Tax To improve economic and trade relations with other countries, a special legal instrument (lex specialist) is required which regulates the tax collection rights of each country to provide legal certainty and avoid the imposition of double taxation and prevent tax evasion. The forms and materials refer to international conventions and other provisions as well as the national taxation provisions of each country.

According to the income tax law, the legal standing of the Double Taxation Avoidance Agreement (P3B) is as a special rule (lex specialist) before the Income Tax Law. So that if provisions 
are governing the same thing, the provisions of the P3B will be applied.

Indonesia adheres to a combination of the UN Model and the basic principles contained in the national tax law. The combination of the two models resulted in a model called the Indonesian Model which became the basis for negotiations on the Double Taxation Avoidance Agreement (P3B) (Surahmat, 2000).

2. State Tax Collection Rights Method for Double Taxation Avoidance Agreement (P3B)

This method stipulates that the Republic of Indonesia has legal power in it which regulates the community or international bodies, and is determined unilaterally by the Republic of Indonesia itself, in other words, no one can regulate our country because it is the authority and sovereignty of the state.

The application of this method is the enactment of Law Number 7 of 1983 as last amended by Law Number 36 of 2008 concerning Income Tax (PPh). Article 26 states that income tax is imposed/deducted on income originating from Indonesia which is received or obtained by a foreign taxpayer other than a permanent establishment (BUT) in Indonesia. If there is no tax treaty agreement or international convention, then the State of Indonesia has the right or authority to determine the amount of tax owed to the international community or international entity that receives income from the Indonesian State.

4.2 Prevention of Abuse in the Implementation of Double Taxation Avoidance Agreement (P3B)

Indonesia has regulations that stipulate that not all Foreign Tax Subjects (SPLN) can immediately use a tax treaty. The Directorate General of Taxes may ignore the certificates held by the SPLN so that the domestic provisions that apply are as regulated in Law Number 7 of 1983 Article 26 and the last amended by Law Number 36 of 2008 concerning Income Tax.

In the regulation of the Directorate General of Taxes Number: PER-24/PJ/2010 concerning amendments to the regulation of the Directorate General of Taxes Number: PER61/PJ/2009 concerning Procedures for the Application of Double Taxation Avoidance Agreement (P3B). From the contents of the regulation, it can be seen that the definition of misuse of $\mathrm{P} 3 \mathrm{~B}$ referred to in the regulation can occur if:

1. Transactions that do not have economic substance are carried out using such a structure/scheme with the sole purpose of obtaining the benefits of the Tax Treaty.

2. Transactions with a structure/scheme whose legal form is different from the economic substance in such a way with the sole purpose of obtaining the benefits of Tax Treaty; or

3. The income recipient is not the actual owner of the economic benefits of the income (beneficial owner).

\section{CONCLUSION}

The double taxation treaty $(\mathrm{P} 3 \mathrm{~B})$ is an international treaty. In the Indonesian legal system, double taxation treaties (P3B) then become part of the legislation, and the provisions are higher than the national law. And as a special rule (lex specialist) before the "Income Tax Law". Therefore, if there is a regulation that regulates the same thing, then the $\mathrm{P} 3 \mathrm{~B}$ regulation will be enforced. After the agreement is approved, this Tax Treaty becomes part of national law. Because the $\mathrm{P} 3 \mathrm{~B}$ is an agreement in the economic field, there is no need for DPR approval, as long as the presidential decision is sufficient.

One of the violations in avoiding double taxation agreements $(\mathrm{P} 3 \mathrm{~B})$ is that the recipient of the income is not the true owner (beneficiary owner) of the economic benefits of the income. In this kind of abuse, double taxation avoidance agreements (P3B) can be anticipated at the time of registration or when a foreign tax agency (SPLN) applies to collect the income. It can be seen that the SPLN is the only source of income and has economic significance.

\section{REFERENCES}

[1] Aghnia, A. 2016, Analysis of Double Taxation Avoidance Agreement (P3b) in the System Law in Indonesia.

[2] Brotodihardjo, R. Santoso, 2008, Introduction to Tax Law, Bandung: Refika Aditama.

[3] Bryan, A.G. (1999), Black's Law Dictionary. London: West Thomas Reuters Publisher.

[4] Maghfiroh, L. 2012, The Effect of the Implementation of the Double Taxation Avoidance Agreement between Indonesia-China Against Indonesia-China International Trade.

[5] Sony Devano and Siti Kumia R. 2006. Taxation, Concepts, Theory, and Issues.

[6] Jakarta: Kencana Prenada Media Group.

[7] Suandi, Erly, 2008, Tax Law, Jakarta: Salemba Empat.

[8] Surahmat, R. (2000), Double taxation avoidance agreement: an introduction / Rachmanto Surahmat.

[9] Zain, M. 2007, Tax Management (3rd Edition), Jakarta: Salemba Empat.

\section{AUTHORS}

First Author - Aflintua H. Sormin (BC202120211), Graduate Student, Institut Stiami Jakarta

Second Author - Alhabieb Amanggori (BC202120119), Lecturer, institut Stiami Jakarta

Third Author - Dr.Prianto Budi Saptono, Lecturer, institut Stiami Jakarta 